\title{
Using Environmental, Social, Governance (ESG) and Financial Indicators to Measure Bank Cost Efficiency in Asia
}

\author{
Hai-Yen Chang (D), Lien-Wen Liang *(D) and Yu-Luan Liu \\ Department of Banking \& Finance, Chinese Culture University, Taipei City 11114, Taiwan; \\ irischang1014@gmail.com (H.-Y.C.); 4334031allen@gmail.com (Y.-L.L.) \\ * Correspondence: liang.lienwen@gmail.com; Tel.: +886-2-2861-0511 (ext. 36237)
}

Citation: Chang, H.-Y.; Liang, L.-W.; Liu, Y.-L. Using Environmental,

Social, Governance (ESG) and

Financial Indicators to Measure Bank Cost Efficiency in Asia. Sustainability 2021, 13, 11139. https://doi.org/ $10.3390 /$ su132011139

Academic Editors: David Aristei, Manuela Gallo and Olaf Weber

Received: 11 August 2021

Accepted: 5 October 2021

Published: 9 October 2021

Publisher's Note: MDPI stays neutral with regard to jurisdictional claims in published maps and institutional affiliations.

Copyright: () 2021 by the authors. Licensee MDPI, Basel, Switzerland. This article is an open access article distributed under the terms and conditions of the Creative Commons Attribution (CC BY) license (https:// creativecommons.org/licenses/by/ $4.0 /)$.

\begin{abstract}
Environmental, social, and governance (ESG) practices have been used as non-financial indicators to measure bank performance worldwide in the last decade. The United Nations (UN) has specified 17 Sustainable Development Goals (SDGs) for the implementation of these ESG concepts. However, it remains unclear whether the costs of ESG have exceeded the benefits. The purpose of this study is to examine the impact of ESG on the cost efficiency of developed and developing Asian banks using a two-step approach comprising stochastic frontier analysis (SFA) and stochastic metafrontier analysis (SMF). The data sample from 2015 to 2018 is separated into two groups: 60 Asian developed economies and 85 developing economies. The results show that banks in the developed Asian economies become more cost-efficient through environmentally friendly activities. The banks in the developing Asian economies increase their cost efficiency by socially responsible activities and improved governance. Moreover, banks in the developed Asian economies outperformed those in the developing Asian economies in terms of technology gap ratio (TGR) and metafrontier cost efficiency (MCE). The results of this study benefit not only investors and bank managers but also the entire banking sector and the world economy.
\end{abstract}

Keywords: ESG; sustainable development goals (SDGs); bank efficiency; bank cost; stochastic frontier analysis; stochastic metafrontier analysis

\section{Introduction}

Financial institutions play an important role in national and international trade, and in the process of globalization. Banks serve as intermediary institutions for intermediation, channeling funds from savers to borrowers to enable business developments and investments [1]. Financial institutions are also crucial in the international markets because banks support companies in conducting international trade in which foreign exchange and letters of credit are often needed. Furthermore, banks facilitate the globalization process. Banks provide their customers with convenient and low-cost ways, such as an internet banking system, to pay and track funds [2]. In addition, banks assist multinational firms in achieving foreign direct investments and listing their stocks in overseas countries, thus helping these corporations to expand globally.

Karray and Chichti [3] claimed that banks must achieve optimal performance to support regional development and strengthen their function as intermediary institutions. Efficiency is an important indicator of bank performance which is measured mostly by financial data. Battese and Coelli [4] began to use bank efficiency to measure bank performance, followed by other researchers [5-7]. Efficiency is measured by comparing inputs such as cost of borrowed funds, cost of tangible assets and labor, against outputs such as loans, income-generating assets, and deposits. It is essential to measure bank efficiency because the failure of the bank or inadequate cash due to loan collection problems jeopardizes the economic lives of millions of individuals [8]. Miralles-Quiros et al. [9] expected banks to play a dual role concerning the sustainability of the financial sector with one involving 
financial performance and the other corporate governance and social responsibilities at a strategic level $[10,11]$. Banks must not only focus on profitability but also on corporate governance [12,13].

In 2005, the United Nations (UN) proposed the Principles for Responsible Investment (PRI) which highlighted environmental, social, and governance (ESG) issues [14]. In 2015, the UN further announced the 17 Sustainable Development Goals (SDGs) of the 2030 agenda for sustainable development [15]. As intermediary institutions, banks primarily use the funds from their depositors to conduct banking business; therefore, banks must monitor the cost-benefit effect more prudently in order to safeguard their depositors' money. Banks' efficiency in using such funds is a crucial indicator of bank sustainability in the long run. Although it is important for banks to execute ESG practices, the literature examining whether banks generate more revenue as a result of implementing ESG programs to cover the associated expenditures is scant. Consequently, it remains unclear whether the implementation and disclosure of ESG activities increased or decreased bank cost efficiency. Moreover, prior research using regression models to analyze bank financial performance also mostly focused on the performance of banks in the developed countries, such as the U.S. and Europe. Few studies discussed the efficiency of the rapidly growing banking industry in Asia. This study fills such a research gap.

The purpose of this study is to examine the impact of ESG on the cost efficiency of developed and developing Asian banks using a two-step approach comprising stochastic frontier analysis (SFA) developed by Battese and Coelli [4] and stochastic metafrontier analysis (SMF) proposed by Huang et al. [6]. We divided the Asian banks into two groups based on the International Monetary Fund (IMF) definitions. One group included 60 banks in five developed Asian economies. The other group included 85 banks in 13 developing Asian economies. In the first step, we investigated the impact of ESG and bank-specific indicators on the efficiency of the two groups of banks. In the second step, we studied the impact of macroeconomic factors on bank efficiency and compared the technology gap ratio (TGR) and metafrontier cost efficiency (MCE) of the two groups of banks.

The results indicate that environment variables significantly increased bank cost efficiency in the developed economies, but not in the developing economies. The social and governance variables increased bank cost efficiency in the developing economies, but not in the developed economies. In addition, banks in the developed economies exhibited higher cost efficiency than their counterparts in the developing economies in Asia.

The study contributes to the literature in three ways. First, to the best of our knowledge, this is the first study to incorporate the 17 SDGs to examine bank cost efficiency. Second, this study compared the cost efficiency of banks in developed and developing economies in the fast-growing Asian region, which was rare in the literature. Third, this is the first study to apply SFA and SMF to analyze the impact of ESG on Asian bank cost efficiency. The results of this study benefit not only the bank managers and investors but also the entire banking sector.

\section{Literature Review}

Dahl et al. [16] elucidated that the western countries led the development of the modern banking industry around the world in terms of size, growth, business models, and innovation. However, in the last decade, Asian banks have expanded quickly and developed innovative products designed to satisfy the needs of a larger group of customers. This change reflects not only the increasingly important role of Asian banks in global trade and economic growth but also Asia's leadership in delivering new technologies and business models. From 2016 to 2021, the top five largest banks by asset size (Industrial \& Commercial Bank of China, China Construction Bank, Agricultural Bank of China, Bank of China, Japanese Mitsubishi Bank) were in Asia [17].

In addition, more than 40 of the world's 100 largest banks based on asset size are Asian, accounting for approximately 50\% of global market capitalization [16]. Moreover, Asia was the largest regional banking market in the world for the last decade. On the 
whole, the Asian banks generated pretax profits exceeding $\$ 700$ billion, which accounted for $37 \%$ of the global banking profit. With the rise of the income level of the middle-class group in Asia, Dahl et al. [16] expected the financial assets held by households in Asia to reach $\$ 69$ trillion by 2025 , representing approximately $75 \%$ of the global amount.

Despite the growth of the financial sector, banks are affected by systemic risks, which arise when a set of adverse events in the markets threatens to disrupt the bank functions of intermediation [2]. The systemic risk in the economy, such as a decline in the gross domestic product (GDP) and high unemployment rate, could lead to the instability of the banking system. For instance, a high unemployment rate is likely to aggravate the default rate of bank loans, which impedes further bank lending and tightens bank credit policy, leading to a recession and widespread failure of loan payment. Such results hamper the bank's role in facilitating economic growth.

\subsection{ESG}

The PRI announced by the UN in 2005 highlighted the influence of ESG issues on the performance of investment portfolios. Subsequently, guidelines for environmental stewardship, social responsibility, and corporate governance gradually directed the evaluation of the firms. Environmental stewardship refers to the firm's actions concerning the natural environment with a focus on the reduction in waste and pollution, greenhouse gas emissions, and climate change [14]. Social responsibility is similar to the concept of corporate social responsibility (CSR). Social responsibility means fair and beneficial business practices for labor, respect for human rights, the establishment of a safe environment, and service to the community [14]. Governance refers to the proper management of the company in addition to economic prosperity. Firms should formulate appropriate policies, especially related to business ethics, disclosure of information, and board composition to govern their business operations [18].

In 2015, the UN announced the 17 SDGs which can be divided into five categories: people (no poverty, zero hunger, good health and well-being, quality education, gender equality), planet (clean water and sanitation, affordable and clean energy, climate action, life below water, life on land), prosperity (decent work and economic growth, industry, innovation, and infrastructure, responsible consumption and production), peace (reduced inequality, sustainable cities and communities, peace, justice, and strong institutions), and partnership (entering into partnerships to reach the goals) [15].

In 2018, the UN released a report entitled "Integrating the SDGs into Corporate Reporting: A Practical Guide", to help corporations to set objectives and disclose their ESG activities. In 2018, approximately $40 \%$ of the world's 250 largest companies reported SDGs and included the global goals in their annual reports [19]. The achievements of the SDGs by all nations would create new opportunities and an increase in efficiency for an estimated $\$ 12$ trillion in four economic systems: food and agriculture, cities, energy and materials, and health and well-being [19].

In 2018, the UN established a special task force to analyze the relationship between ESG investing and returns. The UN also recommended aligning financial systems with sustainable development. Prior researchers began to examine the impact of the disclosure of ESG activities on bank performance.

\subsection{Environmental}

The stakeholder theory explains the dynamics of ESG and shareholder value [20]. Shareholders are the primary stakeholders in a firm; hence companies should perform business activities to maximize shareholder interests. Therefore, negative consumer attitudes toward a firm's products and services or non-compliance with government regulations and environmental practices may decrease shareholder value [21].

However, ESG may increase bank expenditures due to the additional investment requirements in environmental activities, such as reduction in carbon emissions, use of renewable energy, prevention of air and water pollution, planting trees, etc. Many banks 
implemented environmental activities as a result of government requirements that need to be considered when evaluating the performance of listed firms [18]. The question of whether over-investment in environmental activities leads to a favorable financial position remains unanswered in the literature [22].

Prior studies indicated that the impact of environmental activities on bank performance varied. Some researchers found that environmentally friendly activities improved a bank's financial performance. In other words, banks that disclosed efforts of minimizing carbon emissions generated greater profits. Such disclosure also increased the bank's market value [14]. Buallay [23] studied the performance of 235 banks from 2007 to 2016 and ascertained that environmental disclosure positively affected the banks' return of assets (ROA) and market value as measured by Tobin's Q. Similarly, Miralles-Quirós et al. [24] studied 51 banks in the U.S. and Europe from 2002 to 2015. These authors claimed that environmental endeavors positively influenced the banks' market value and earnings per share (EPS). Crespi et al. [18] examined ESG activities and financial performance using data for 727 financial firms from 22 developed countries from 2006 to 2017. The results revealed that a higher environmental score led to increased profitability.

In contrast, other studies found that the disclosure of environmental activities had a negative impact on banks. For example, Forgione et al. [5] used a one-step SFA method to examine ESG and bank efficiency in primarily developed economies from 2013 to 2017. They found the disclosure of environmental activities reduced bank efficiency. Similarly, Dell'Atti et al. [25] investigated the impact of the banking industry during the 2008 subprime mortgage crisis by studying the correlation between bank reputation and economic performance. The results suggested that environmental activities had a negative but insignificant effect on reputation and bank performance. In a study by Di Tommaso and Thornton [26], the European banks that received high ESG scores by engaging in more carbon-emission-reduction activities became less willing to take a risk, thus diminishing bank value for the shareholders.

Following the practices of banks in the U.S. and Europe, banks in Asia also invested in environment-friendly activities. These environment-friendly policies may produce a positive influence on bank performance in the medium to long run.

Therefore, we developed the first hypothesis:

Hypothesis 1 (H1). Environmental variables have a positive impact on bank cost efficiency.

\subsection{Social}

CSR can be explained by the stakeholder theory [27]. The theory states that firms should service a multitude of stakeholders, including shareholders, customers, and employees, rather than shareholders only, so that firms may boost the popularity of products and financial performance [20].

These CSR activities include the production of high-quality products and services for customers, payment of fair salaries to employees, provision of health care and educational programs to the community, in addition to profit maximization for shareholders. However, previous studies found the relationship between social activities and firm performance to be mixed.

Some studies of developed countries such as the U.S., Canada, and other European countries revealed a negative relationship between the disclosure of social activities and bank performance in terms of earnings and ROA because the large costs of social welfare exceeded the benefits $[9,11,23,26]$.

However, CSR may produce a positive influence on bank performance due to a better perception of the stakeholders of the firm's attitude toward social responsibility. Shakil et al. [22] argued that because stakeholders were more interested in the firms' disclosure of social activities, and the implementation of CSR programs may lead to an overall improvement of the firm performance. Dell'Atti et al. [25] studied the correlation between firm reputation and economic performance using 75 large international banks 
during the 2008 subprime mortgage crisis. The results suggested that social welfare was positively correlated with firm reputation with some possibility of improving the firms economic performance. Similarly, Forgione et al. [5] found that the disclosure of CSR activities had a positive impact on bank efficiency only in common law countries, such as the U.S., Australia, and countries with stakeholder protection. These studies confirmed the stakeholder theory that activities benefiting stakeholders increase their contributions to the firms and led to improved financial results.

Therefore, we assumed that CSR activities have a positive relationship with the performance of Asian banks. Thus, we developed the second hypothesis:

Hypothesis 2 (H2). Social variables have a positive impact on bank cost efficiency.

\subsection{Governance}

Corporate governance refers to the proper management of a company. For instance, firms should follow good business ethics, as well as disclosure and accountability practices [22]. Sustainable business policies cover the areas such as disclosure of financial and operational information to increase stakeholders' confidence in the company, gender equality, board diversity to allow various opinions on the firm operations, and so on [28].

The agency theory explains the reasons for the increasing importance of good corporate governance over the last decade. According to agency theory, a conflict between shareholders and managers occurs when management interests are not aligned with those of the shareholders [29]. Good corporate governance aims to align the interests of shareholders and managers so that the two groups of people cooperate to strengthen firm performance [5]. Hence, companies with strong corporate governance may reduce the conflict between shareholders and managers [30]. Companies with poor corporate governance are likely to face high agency problems and lower profitability [24].

Prior studies reported mixed results regarding the impact of corporate governance on bank performance $[9,11,12,23,31,32]$. Birindelli et al. [32] used a fixed-effects panel regression model to analyze the relationship between the composition of the board of directors and the ESG performance among 108 listed banks in the U.S. and Europe from 2011 to 2016. They used female directors, the board size, CSR committee as the governance variables. The empirical results presented an inverted U-shaped relationship between the female directors and firm performance. The evidence suggested that only a genderbalanced board had a positive impact on the bank's overall ESG performance. In addition, ESG programs produced a positive impact on the board size and the existence of the CSR committee. Miralles-Quirós et al. [9] investigated the relationship between ESG and bank performance using 51 banks in the U.S. and Europe from 2002 to 2015. The results indicated that governance had a positive influence on market value and EPS. In addition, Miralles-Quirós et al. [11] scrutinized ESG and bank financial performance in Europe and found that the governance factor produced a positive effect on bank market value.

However, other researchers found governance negatively affected bank performance in emerging countries and some European countries [12,23,31]. Azmi et al. [12] examined the relationship between the disclosure of ESG activities and bank value based on 251 banks from 2011 to 2017 from 40 emerging economies. The results revealed that governance had a negative impact on bank market value. El Khoury et al. [31] investigated the financial performance of 46 banks in the Middle East, North Africa, and Turkey (MENAT region) from 2007 to 2019. The empirical evidence showed that in the long run, bank costs exceeded the benefits of social and governance programs. Similarly, Buallay [23] found that governance disclosure negatively impacted the financial performance of European banks.

Based on the assumption that governance benefits bank performance, we developed the third hypothesis:

Hypothesis 3 (H3). Governance has a positive impact on bank cost efficiency. 


\subsection{Financial Variable}

Prior studies used bank-specific (loan, deposits, interest, etc.) and macroeconomic indicators (unemployment rate, GDP, etc.) of the countries in which banks were headquartered to examine bank performance $[2,7,10,23,31]$. The combination of bank-specific and macroeconomic indicators provided for a comprehensive analysis of the banks and revealed the factors that contributed the most to bank performance.

\subsection{SFA and SMF}

Battese and Coelli [4] proposed SFA to examine the cost inefficiency of the panel data of firms. Subsequently, Huang et al. [6] proposed SMF to compare the efficiencies of different decision-making units (DMU) by computing their TGR and MCE. Banks in various countries used different knowledge and technologies to develop their products and services. The difference in technology, measured by TGR, contributed to the variations in bank performance $[6,33]$.

Based on the literature review, this paper uses a two-step stochastic frontier analysis process composed of SFA and SMF to estimate the cost inefficiency of two groups of banks adopting distinct technologies [34]. In the first step of the analysis, the within-group variation in the firms' technical efficiencies, which is frequently associated with firm-specific exogenous variables, is calculated [4]. In the second step, the between-group variation in the technology gap ratios which commonly stems from group-specific environmental differences is computed [6]. The two-step stochastic frontier analysis is more powerful than the conventional regression models because the two-step analysis not only identifies the significant variables affecting bank cost efficiency but also compares the cost efficiency of two groups of banks.

\section{Method}

\subsection{Data Collection}

This study collected data for 145 banks located in Asian economies from 2015 to 2018, from the BankFocus database. The data were separated into two groups for a comparison of the bank's efficiency based on the bank classification by the IMF [35]. The IMF classifies countries/regions into advanced (known as "the developed economies") and emerging and developing economies (referred to as "the developing economies") by three main criteria: GDP per capita, export diversification (a country/region must export a wide array of commodities, not just a few commodities to be considered "developed economy"), and integration into the global financial system (including both an economy's volume of international trade and its adoption of and participation in international financial institutions). The IMF uses either the sums of the weighted average of data for individual countries/regions. This study adopts the IMF bank classification that is readily available but moves China to the developed economy group considering China has become the second-largest economy in the world by GDP since 2010 and has occupied nearly $20 \%$ of the top 100 banks in the world since 2015.

As the result of the bank division, one group of this study contained the data for 60 banks from five developed economies (China, Hong Kong, Japan, Korea, and Taiwan) with 240 observations. The other group included the data for 85 banks from 13 developing economies such as India and Pakistan, with 340 observations. Table 1 lists the banks in the two groups of developed and developing economies. 
Table 1. Division of banks into the developed and developing economies.

\begin{tabular}{cccccc}
\hline Year & $\mathbf{2 0 1 5}$ & $\mathbf{2 0 1 6}$ & $\mathbf{2 0 1 7}$ & $\mathbf{2 0 1 8}$ & Total \\
\hline China & 18 & Developed Economy & & \\
Hongkong & 10 & 18 & 18 & 18 & 72 \\
Japan & 13 & 10 & 10 & 10 & 40 \\
Korea(S) & 9 & 9 & 13 & 13 & 52 \\
Taiwan & 10 & 10 & 9 & 9 & 36 \\
\hline Total & 60 & 60 & 10 & 10 & 40 \\
\hline Afghanistan & 1 & Developing Economy & 60 & 240 \\
Banglandesh & 7 & 1 & 1 & 1 & 4 \\
India & 34 & 7 & 7 & 7 & 28 \\
Kazakhstan & 7 & 34 & 34 & 34 & 28 \\
Kyrgyzstan & 1 & 7 & 7 & 7 & 4 \\
Malaysia & 5 & 1 & 1 & 1 & 20 \\
Mongolia & 1 & 5 & 5 & 5 & 4 \\
Nepal & 6 & 1 & 1 & 1 & 40 \\
Pakistan & 10 & 6 & 6 & 6 & 12 \\
Philippines & 3 & 10 & 10 & 10 & 20 \\
Srilanka & 5 & 3 & 3 & 3 & 16 \\
Thailand & 4 & 5 & 5 & 5 & 4 \\
Vietnam & 1 & 4 & 4 & 4 & 340 \\
\hline Total & 85 & 1 & 1 & 85 & \\
\hline
\end{tabular}

\subsection{Variables and Definitions}

The intermediation approach proposed by Sealey and Lindley [36] defines the relationship of input and output used in the efficiency measurement. This approach focuses on bank activities performing the function of intermediation to distribute savers' deposits to borrowers in the form of loans [3,37]. In other words, the efficiency of the bank is measured by its ability to convert resources into income-generating financial assets.

Based on the literature review $[7,8,36]$, the inputs of this study are deposits, labor, and fixed assets. However, we found the data on the number of employees either missing or unavailable for many Asian banks in the sample; we therefore used total assets to indicate labor based on the literature by Altunbas et al. [38], Altunbas et al. [39], Gaganis and Pasioura [40], Weill [41], Fries and Taci [42], Huang et al. [43]. In the previous studies, the price of labor was defined as the ratio of personnel expenses to total assets. Hence, the price of labor is significantly correlated with total assets. Therefore, this study used total assets as the proxy for labor input [38-43]. The outputs are loans, investment, and fee income. Table 2 lists the inputs, outputs, definitions, and descriptive statistics.

The outputs are loans, investment, and fee income. We obtained the means of input and output variables of the two bank groups from the T-test, which shows a significant difference between the two bank groups. Table 2 lists the inputs, outputs, definitions, and descriptive statistics.

Both non-financial and financial variables are used to measure bank efficiency in this study based on the literature. This study adopts both non-financial and financial variables to measure bank efficiency $[7,8]$. The non-financial variables are the 17 SDGs by the UN and its divisions into the three dimensions of ESG [14]. The UN provided the ESG score indicated by a color scheme for each economy. The green color indicates "good SDG achievement" with a score of 3 . The yellow and orange colors (orange colors only available from 2017) mean "challenges remained" and "significant challenges" with a score of 2 . The red color means "a major challenge" with a score of 1 . The UN gave a higher score for better ESG performance of an economy. 
Table 2. Definitions of Variables and Descriptive Statistics.

\begin{tabular}{|c|c|c|c|c|}
\hline Variables & Definition & Developed Economy & Developing Economy & t Value \\
\hline & & Mean & Mean & \\
\hline $\begin{array}{l}\text { Total Cost (TC) } \\
\text { (million USD) }\end{array}$ & $\begin{array}{l}\text { Labor cost }+ \text { Capital cost }+ \\
\text { Funding cost }\end{array}$ & $\begin{array}{c}6,499,063 \\
(14,914,637)\end{array}$ & $\begin{array}{c}677,066 \\
(1,019,084)\end{array}$ & $7.177^{* * *}$ \\
\hline $\begin{array}{c}\text { Output } \\
\text { Loans (Y1) } \\
\text { (million USD) }\end{array}$ & Loans & $\begin{array}{c}165,285,597 \\
(383,233,910)\end{array}$ & $\begin{array}{c}8,622,639 \\
(13,732,876)\end{array}$ & $7.534^{* * *}$ \\
\hline $\begin{array}{l}\text { Investments (Y2) } \\
\text { (million USD) }\end{array}$ & Investments & $\begin{array}{c}97,147,466 \\
(214,135,742)\end{array}$ & $\begin{array}{c}3,763,981 \\
(5,918,764)\end{array}$ & $7.036^{* * *}$ \\
\hline $\begin{array}{l}\text { Noninterest income (Y3) } \\
\text { (million USD) }\end{array}$ & Non-interest income & $\begin{array}{c}1,378,710 \\
(3,519,554)\end{array}$ & $\begin{array}{c}107,359 \\
(212,930)\end{array}$ & $6.646^{* * *}$ \\
\hline $\begin{array}{c}\text { Input } \\
\text { Funding (X1) } \\
\text { (million USD) }\end{array}$ & Deposits + Borrowing & $\begin{array}{c}237,796,753 \\
(574,427,451)\end{array}$ & $\begin{array}{c}11,118,874 \\
(16,804,436)\end{array}$ & $7.275^{* * *}$ \\
\hline $\begin{array}{c}\text { Labor (X2) } \\
\text { (million USD) }\end{array}$ & Total assets & $\begin{array}{c}301,638,981 \\
(695,877,521)\end{array}$ & $\begin{array}{c}14,281,769 \\
(22,166,301)\end{array}$ & $7.612^{* * *}$ \\
\hline Capital (X3) & Net fixed assets & $\begin{array}{c}2,507,191 \\
(6,209,124)\end{array}$ & $\begin{array}{c}178,012 \\
(292,881)\end{array}$ & $6.909 * * *$ \\
\hline Price of funding (P1) & $\begin{array}{l}\text { Interest payments /(Deposits } \\
\text { + Borrowing) }\end{array}$ & $\begin{array}{c}0.015 \\
(0.015)\end{array}$ & $\begin{array}{c}0.049 \\
(0.020)\end{array}$ & $-22.692 * * *$ \\
\hline Price of labor (P2) & $\begin{array}{c}\text { Employee salaries/Total } \\
\text { employees }\end{array}$ & $\begin{array}{l}0.005 \\
(0.002)\end{array}$ & $\begin{array}{c}0.012 \\
(0.006)\end{array}$ & $-17.829 * * *$ \\
\hline Price of capital (P3) & $\begin{array}{l}\text { Operating expenses/Net } \\
\text { fixed assets }\end{array}$ & $\begin{array}{c}0.311 \\
(0.498)\end{array}$ & $\begin{array}{l}0.536 \\
(0.566)\end{array}$ & $-4.945^{* * *}$ \\
\hline
\end{tabular}

Notes: 1. Standard deviations are expressed in parentheses. 2. All the data were deflated using the consumer price index from the IMF with the year 2010 as the base year. 3. *** indicates significance levels of $1 \%$.

The financial variables are divided into bank-specific variables and macroeconomic variables for the economies in which the banks were headquartered $[2,10,23,31]$. The literature used the bank-specific financial indicators as variables to show the distinct characteristics of banks [43-46]. Pasiouras and Kosmidou [44] used cost-to-income ratio, liquidity ratio, equity ratio, and asset size. Liang, Chang, and Lin [45] adopted non-performing loans (NPL), loan-loss-reserve ratio, and non-interest expense ratio. The rationale for using the cost-to-income ratio is that it indicates the efficiency of cost management, measuring the degree to which banks generate revenues relative to expenses. Higher cost-to-income ratios imply less efficient cost/profitability management [44]. The major element of bank cost is employee salaries and benefits.

The macroeconomic variables include unemployment rate, gross domestic product (GDP) per capita, and GDP growth rate. Table 3 shows the inefficiency variables and their definitions.

Table 3. Definitions of Inefficiency Variables.

\begin{tabular}{ll}
\hline ESG Variables & Definitions \\
\hline & Seven SDGs: \\
& clean water and sanitation, affordable and clean energy, sustainable cities and communities, \\
& responsible consumption and production, climate action, life below water, life on land. \\
& Each variable is assigned a value between 1 and 3 by UN with a higher value meaning higher \\
achievement in this area. & Six SDGs: \\
& no poverty, zero hunger, good health and well-being, quality education, decent work, and \\
& economic growth, reduction in inequality. \\
Each variable is assigned a value between 1 and 3 by UN with a higher value meaning higher & \\
& achievement in this area. \\
\hline
\end{tabular}


Table 3. Cont.

\begin{tabular}{ll}
\hline ESG Variables & Definitions \\
\hline Governance $(G)$ & $\begin{array}{l}\text { Four SDGs: } \\
\text { innovation, gender equality, peace, partnership for the goals. } \\
\text { Each variable is assigned a value between } 1 \text { and } 3 \text { by UN with a higher value meaning higher } \\
\text { achievement in this area. }\end{array}$ \\
\hline Bank Financial Variables and Macroeconomic Variables \\
\hline SFA & Bank-specific variables \\
\hline NPL ratio & Calculated as non-performing loan/total outstanding loan amount \\
BIS ratio & BIS Capital Adequacy Ratio calculated as the amount of capital/risk-weighted assets \\
Cost-to-income ratio & Operating expenses/operating income of the bank \\
Loan loss reserve ratio & Loan loss reserve amount/outstanding loan amount \\
Liquidity ratio & Current assets/total deposits plus short-term funds (Note 1) \\
Non-interest expense ratio & Non-interest expenses/assets (Note 2) \\
\hline SMF & Bank-specific and macroeconomic variables \\
\hline Asset size & The natural logarithm of total bank assets \\
Unemployment rate & Number of unemployment/labor force \\
GDP per capita & GDP/population \\
\hline
\end{tabular}

Note: 1 . The Hong Kong Monetary Authority (HKMA) defines the net stable fund ratio as available stable funds divided by expected stable funds. However, this study computes the liquidity ratio by taking liquid assets divided by total deposits plus short-term funding, due to a lack of data on the net stable fund ratio. 2. non-interest expense refers to an operating expense separated from interest expense and loan loss reserves. Non-interest items include payroll, rent, utilities, information technology costs, etc.

\subsection{SFA}

In the first step of the analysis, we applied SFA as proposed by Battese and Coelli [5]. The stochastic cost frontier function is set as translog, based on Christensen et al. [47], which is homogeneous at the first degree [42,48-50]. In order to eliminate the heteroskedasticity problem, we also used the price of labor $\left(P_{2 i t}\right)$ to normalize total costs and input prices proposed by Allen and Rai [51], Berger and Mester [52], Kraft et al. [50]. The cost function is set as Equation (1):

$$
\begin{aligned}
\ln \left(\frac{T C_{i t}}{P_{2 i t}}\right)= & \alpha_{0}+\alpha_{1} \ln Y_{1 i t}+\alpha_{2} \ln Y_{2 i t}+\alpha_{3} \ln Y_{3 i t}+\beta_{1} \ln \left(\frac{P_{1 i t}}{P_{2 i t}}\right)+\beta_{2} \ln \left(\frac{P_{3 i t}}{P_{2 i t}}\right)+\frac{1}{2} \delta_{11}\left(\ln Y_{1 i t}\right)^{2}+\frac{1}{2} \delta_{22}\left(\ln Y_{2 i t}\right)^{2} \\
& +\frac{1}{2} \delta_{33}\left(\ln Y_{3 i t}\right)^{2}+\delta_{12} \ln Y_{1 i t} \ln Y_{2 i t}+\delta_{13} \ln Y_{1 i t} \ln Y_{3 i t}+\delta_{23} \ln Y_{2 i t} \ln Y_{3 i t}+\frac{1}{2} \gamma_{11}\left[\ln \left(\frac{P_{1 i t}}{P_{2 i t}}\right)\right]^{2} \\
& +\frac{1}{2} \gamma_{33}\left[\ln \left(\frac{P_{3 i t}}{P_{2 i t}}\right)\right]^{2}+\gamma_{13} \ln \left(\frac{P_{1 i t}}{P_{2 i t}}\right) \ln \left(\frac{P_{3 i t}}{P_{2 i t}}\right)+\rho_{11} \ln Y_{1 i t} \ln \left(\frac{P_{1 i t}}{P_{2 i t}}\right)+\rho_{13} \ln Y_{1 i t} \ln \left(\frac{P_{3 i t}}{P_{2 i t}}\right) \\
& +\rho_{21} \ln Y_{2 i t} \ln \left(\frac{P_{1 i t}}{P_{2 i t}}\right)+\rho_{23} \ln Y_{2 i t} \ln \left(\frac{P_{3 i t}}{P_{2 i t}}\right)+\rho_{31} \ln Y_{3 i t} \ln \left(\frac{P_{1 i t}}{P_{2 i t}}\right)+\rho_{33} \ln Y_{3 i t} \ln \left(\frac{P_{3 i t}}{P_{2 i t}}\right) \\
& +\tau_{1} t \ln Y_{1 i t}+\tau_{2} t \ln Y_{2 i t}+\tau_{3} t \ln Y_{3 i t}+\lambda_{1} t \ln \left(\frac{P_{1 i t}}{P_{2 i t}}\right)+\lambda_{2} t \ln \left(\frac{P_{3 i t}}{P_{2 i t}}\right)+\omega_{1} t+\omega_{2} t^{2}+u_{i t}+v_{i t}
\end{aligned}
$$

where $i$ denotes the $i$-th bank; $t$ denotes the time period; $T C_{i t}$ is the total cost of the $i$-th bank during period $t ; Y_{1 i t}$ is the total loan amount of the $i$-th bank during period $t ; Y_{2 i t}$ is the $i$-th bank's total investment during period $t ; Y_{3 i t}$ is the total fee income of the $i$-th bank during period $t ; P_{1 i t}$ is the funding price (interest) of the $i$-th bank during period $t ; P_{2 i t}$ denotes the labor price of the $i$-th bank during period $t ; P_{3 i t}$ denotes the capital price of the $i$-th bank during period $t ; u_{i t}$ denotes random error, $v_{i t} \sim N\left(0, \sigma_{v}^{2}\right)$ means statistical noise. Nonnegative random errors $u_{i t}$ represent cost inefficiency, which follows the truncated-normal distribution as $u_{i t} \sim N^{+}\left(m_{i t}=\delta^{\prime} Z_{i t}, \sigma_{u}^{2}\right) . u_{i t}$ and $v_{i t}$ are independent of each other.

The inefficiency model used in this study is expressed in Equation (2):

$$
m_{i t}=\theta_{0}+\theta_{1} Z_{1 i t}+\theta_{2} Z_{2 i t}+\theta_{3} Z_{3 i t}+\theta_{4} Z_{4 i t}+\theta_{5} Z_{5 i t}+\theta_{6} Z_{6 i t}+\theta_{7} Z_{7 i t}+\theta_{8} Z_{8 i t}+\theta_{9} Z_{9 i t}
$$

where $\theta$ denotes the estimated parameter; and $Z_{i t}$ the inefficiency parameter. The inefficiency variables include ESG (environmental $\left(Z_{1 i t}\right)$, social $\left(Z_{2 i t}\right)$, governance $\left(Z_{3 i t}\right)$ with 
a score of 1 to 3 assigned by the UN, NPL ratio $\left(Z_{4 i t}\right)$, BIS ratio $\left(Z_{5 i t}\right)$, cost-to-income ratio $\left(Z_{6 i t}\right)$, liquidity ratio $\left(Z_{7 i t}\right)$, loan loss reserve ratio $\left(Z_{8 i t}\right)$, and non-interest expense ratio $\left(Z_{9 i t}\right)$.

\section{4. $S M F$}

The second step of this analysis uses SMF as proposed by Huang et al. [7] to estimate the metafrontier cost function, and then measure the inefficiency of different DMUs. The SMF approach not only includes statistical inferences to replace the mathematical programming technique when estimating group frontiers but also considers error terms and group heterogeneity.

Prior literature discussed heterogeneous market structures and measured systemic risk based on the capital flows between groups of banks [53] or based on banks' market returns which are aggregated in bank groups [54].

We first applied SFA to estimate the group-specific frontier cost, then used SMF to estimate the metafrontier cost. Moreover, the SMF approach can directly estimate the technology gaps which are represented by the one-sided term. The technology gaps can be further specified as a function of bank-specific variables beyond the control of banks. The metafrontier cost is based on the concept that all DMUs in the various cost groups have potential access to an array of production technologies, but each may choose a particular technology depending on specific circumstances, such as regulation, the environments, risk (systemic risk or non-systemic risk).

The method used in this study is based on the two-step stochastic frontier approach for estimating the metafrontier proposed by Huang et al. [6]. In the first step, prior researchers [6] used the stochastic frontier regression method to estimate the group-specific frontier. In the second step, these researchers applied the stochastic metafrontier regression method to estimate the metafrontier that specifically takes into consideration the estimation error of $\widehat{f}_{t}^{w}\left(X_{w i t}\right)$ in estimating $f_{t}^{w}\left(X_{w i t}\right)$.

The SMA regression method is used to obtain the frontier of cost efficiency (CE) of each bank group. Equation (3) explains that the cost efficiency of the $i^{\text {th }}$ DMU in group $w^{\text {th }}$ at $t^{\text {th }}$ period is accounted for by the group-specific exogenous variables $Z_{w i t}$. The CE calculated using $C E_{i t}=e^{u_{i t}}$ has a value between one and infinity $\left(1<C E_{i t}<\infty\right)$. A lower group's $C E_{i t}$ value means lower cost inefficiency (higher cost efficiency). On the contrary, a higher group's $C E_{k t}$ value means higher cost inefficiency (lower cost efficiency).

Thus, Cost Efficiency (CE) is expressed in Equation (3):

$$
C E_{i t}^{w}=\frac{C_{w i t}}{f_{t}^{w}\left(X_{w i t}\right) e^{V_{w i t}}}=e^{U_{w i t}}
$$

where $w$ denotes a group.

The common underlying metafrontier cost function for all bank groups in the $t$-th period is defined as $\left(f_{t}^{M}\left(X_{w i t}\right)\right)$ [6]. The metafrontier $\left(f_{t}^{M}\left(X_{w i t}\right)\right)$ envelops all individual groups' frontiers $\left(f_{t}^{w}\left(X_{w i t}\right)\right)$, which is expressed in Equation (4):

$$
f_{t}^{w}\left(X_{w i t}\right)=f_{t}^{M}\left(X_{w i t}\right) e^{U_{w i t}^{M}}, w=1,2, \ldots, W ; i=1,2, \ldots, N_{j} ; t=1,2, \ldots, T
$$

Because $U_{w i t}^{M} \geq 1$, the metafrontier cost for all groups must be smaller than or equal to the estimated group cost frontier $f_{t}^{M}\left(X_{w i t}\right) \leq f_{t}^{w}\left(X_{w i t}\right)$. TGR is the distance from the cost frontier of the $w$ group to the metafrontier cost due to differences in the economic or non-economic factors. A higher TGR indicates a greater distance between the cost frontier of one particular group and the metafrontier cost. TGR is calculated using Equation (5).

$$
T G R_{i t}^{w}=\frac{f_{t}^{w}\left(X_{w i t}\right)}{f_{t}^{M}\left(X_{w i t}\right)}=e^{U_{w i t}^{M}} \geq 1
$$


The inefficiency of $D M U_{i}$ under $X_{w i t}$ produces random interference for output $C_{w i t}$ with the group inefficiency captured by $V_{\text {wit }}$ and $U_{w i t}$. Non-negative $U_{w i t}^{M}$ reflects the TGR between the group cost frontier and metafrontier cost. The result indicates that although $D M U_{i}$ has reached the highest cost efficiency within the group, it still has room for improvement when compared to the metafrontier cost.

Based on technology gap ratio expressed as $T G R_{i t}^{w}=\frac{f_{t}^{w}\left(X_{w i t}\right)}{f_{t}^{M}\left(X_{w i t}\right)}$, DMU cost efficiency expressed as $C E_{i t}^{w}=\frac{f_{t}^{w}\left(X_{w i t}\right) e^{U_{w i t}}}{f_{t}^{w}\left(X_{w i t}\right)}=e^{U_{w i t}}$; random errors expressed as $\frac{C_{w i t}}{f_{t}^{w}\left(X_{w i t}\right) e^{u_{w i t}}}=e^{V_{\text {wit }}}$, we can obtain Equation (6):

$$
\frac{C_{w i t}}{f_{t}^{M}\left(X_{w i t}\right)}=T G R_{i t}^{w} \times C E_{i t}^{w} \times e^{V_{w i t}}
$$

The MCE $\left(M C E_{j i t}\right)$ for the bank groups can be expressed using Equation (7):

$$
M C E_{\text {wit }}=\frac{C_{w i t}}{f_{t}^{M}\left(X_{w i t}\right) e^{V_{w i t}}}=T G R_{i t}^{w} \times C E_{i t}^{w}
$$

\section{Results}

\subsection{Descriptive Statistics}

Table 4 exhibits the descriptive statistics for the inefficiency variables for the two groups of banks. Overall, the banks in the developed economies all had higher ESG means than the ones in the developing economies. We further examined each of the ESG variables. Regarding the environmental variable, the means of the banks in the developed and developing economies were 1.64 and 1.56, respectively. Regarding the social variable, the means of the banks in the developed and developing economies were 2.01 and 1.61, respectively. Regarding the governance variable, the means of the banks in the developed economies and developing economies were 1.78 and 1.38, respectively. Moreover, we tested for multicollinearity between the two groups of banks. The results showed the correlation coefficient of each variable between the developed and developing economies to be less than 0.6 ; therefore, the problem of collinearity did not exist. Table 4 provides the descriptive statistics of inefficiency variables.

Table 4. Descriptive Statistics of Inefficiency Variables.

\begin{tabular}{ccccccccc}
\hline \multirow{2}{*}{ Variables } & \multicolumn{3}{c}{ Developed Economy } & \multicolumn{3}{c}{ Developing Economy } \\
\cline { 2 - 8 } & Mean & Std. Dev. & Max & Min & Mean & Std. Dev. & Max & Min \\
\hline E & 1.64 & 0.14 & 1.86 & 1.29 & 1.55 & 0.26 & 2.00 & 1.00 \\
S & 1.99 & 0.17 & 2.33 & 1.67 & 1.53 & 0.24 & 2.17 & 1.00 \\
G & 1.81 & 0.16 & 2.00 & 1.50 & 1.27 & 0.23 & 2.00 & 1.00 \\
NPL ratio & 1.56 & 1.34 & 8.96 & 0.04 & 6.22 & 7.02 & 39.29 & 0.26 \\
BIS ratio & 13.91 & 2.87 & 23.10 & 8.10 & 16.67 & 6.44 & 86.73 & 7.72 \\
Cost to income ratio & 51.45 & 18.10 & 100.60 & 6.82 & 52.63 & 13.38 & 117.51 & 23.07 \\
Loan loss reserve ratio & 143.99 & 134.36 & 1086.86 & 6.17 & 101.68 & 124.04 & 2008.67 & 7.74 \\
Liquidity ratio & 7.50 & 2.07 & 14.59 & 3.97 & 18.62 & 13.96 & 125.94 & 2.93 \\
Non-interest expense ratio & 1.38 & 0.99 & 10.12 & 0.14 & 3.58 & 1.74 & 13.80 & 0.72 \\
\hline
\end{tabular}

\subsection{SFA}

In the first step of the analysis, we applied SFA. Before estimating the stochastic frontier cost functions for the two groups of banks, we performed the likelihood ratio (LR) test to verify whether the proposed inefficiency model was well developed, with Equation (8):

$$
L R=-2\left\{\ln \left[L\left(H_{0}\right)\right]-\ln \left[L\left(H_{1}\right)\right]\right\}
$$


where $\ln \left[L\left(H_{0}\right)\right]$ is the $\log$ likelihood of the translog cost function without the inefficiency variables. $\ln \left[L\left(H_{1}\right)\right]$ is the $\log$ likelihood of the translog cost function with inefficiency variables.

The null hypothesis $\left(\mathrm{H}_{0}\right)$ means that no difference existed between the two groups of banks. The opposite hypothesis $\left(\mathrm{H}_{1}\right)$ assumes the existence of a significant difference between the two groups of banks. The results show that the LR statistic for the banks in the developed Asian countries was 64.5084 and that for developing Asian countries was 87.2316. The statistics of both bank groups are above the Chi-square $X_{0.01,9}^{2}=21.6660$, thus significantly rejecting $\mathrm{H}_{0}$. The results indicate that the inefficiency variables should be included in the SFA method. Thus, the proposed inefficiency model was suitable for this research. Table 5 presents the estimation of stochastic frontier cost functions for the two groups of Asian banks.

Table 5. Stochastic Frontier Cost Functions of Two Groups of Asian Banks.

\begin{tabular}{|c|c|c|c|c|}
\hline \multirow{2}{*}{ Variables } & \multicolumn{2}{|c|}{ Developed Economy } & \multicolumn{2}{|c|}{ Developing Economy } \\
\hline & Estimated Coefficients & t Values & Estimated Coefficients & t Values \\
\hline Constant & $7.1454^{* * *}$ & 3.3275 & $3.1049^{* * *}$ & 3.1889 \\
\hline $\ln Y 1$ & -0.5344 & -1.3695 & 0.0147 & 0.0625 \\
\hline $\ln Y 2$ & $0.8950^{* * *}$ & 3.2612 & $0.7511^{* * *}$ & 5.7416 \\
\hline $\ln Y 3$ & 0.1272 & 0.4463 & 0.0354 & 0.3018 \\
\hline $\ln (\mathrm{P} 1 / \mathrm{P} 2)$ & $1.3582^{* * *}$ & 6.7846 & $0.7174^{* * *}$ & 4.8893 \\
\hline $\ln (\mathrm{P} 3 / \mathrm{P} 2)$ & $-0.5449 * *$ & -2.1368 & $-0.2176^{* *}$ & -1.9674 \\
\hline $1 / 2 \times(\ln Y 1)^{2}$ & $0.2348^{* * *}$ & 3.3777 & $0.2083^{* * *}$ & 7.0339 \\
\hline $1 / 2 \times(\ln Y 2)^{2}$ & 0.0982 & 1.4855 & $0.1301^{* * *}$ & 5.5271 \\
\hline $1 / 2 \times(\ln Y 3)^{2}$ & 0.0137 & 0.6027 & -0.0146 & -1.2515 \\
\hline $\ln Y 1 \times \ln Y 2$ & $-0.1486^{* *}$ & -2.5162 & $-0.1690^{* * *}$ & -9.2538 \\
\hline $\ln Y 1 \times \ln Y 3$ & -0.0337 & -1.1547 & -0.0091 & -0.5532 \\
\hline $\ln Y 2 \times \ln Y 3$ & 0.0202 & 0.7848 & 0.0203 & 1.4088 \\
\hline $1 / 2 \times[\ln (\mathrm{P} 1 / \mathrm{P} 2)]^{2}$ & $0.1241^{* * *}$ & 6.4329 & $0.1871^{* * *}$ & 9.1967 \\
\hline $1 / 2 \times[\ln (\mathrm{P} 3 / \mathrm{P} 2)]^{2}$ & 0.0276 & 1.4265 & $0.0197^{* *}$ & 2.1619 \\
\hline $\ln (\mathrm{P} 1 / \mathrm{P} 2) \times \ln (\mathrm{P} 3 / \mathrm{P} 2)$ & $-0.0464^{* * *}$ & -3.3171 & $-0.0532^{* * *}$ & -5.0083 \\
\hline $\ln \mathrm{Y} 1 \times \ln (\mathrm{P} 1 / \mathrm{P} 2)$ & $-0.0553 *$ & -1.8949 & -0.0106 & -0.6431 \\
\hline $\ln Y 1 \times \ln (\mathrm{P} 3 / \mathrm{P} 2)$ & 0.0087 & 0.2971 & 0.0176 & 1.0977 \\
\hline $\ln Y 2 \times \ln (\mathrm{P} 1 / \mathrm{P} 2)$ & -0.0163 & -0.5230 & 0.0135 & 0.8274 \\
\hline $\ln Y 2 \times \ln (\mathrm{P} 3 / \mathrm{P} 2)$ & 0.0322 & 1.5277 & -0.0053 & -0.5042 \\
\hline $\ln Y 3 \times \ln (\mathrm{P} 1 / \mathrm{P} 2)$ & $0.0254^{* *}$ & 2.0051 & -0.0229 & -1.3842 \\
\hline $\ln Y 3 \times \ln (\mathrm{P} 3 / \mathrm{P} 2)$ & -0.0070 & -0.3823 & 0.0042 & 0.3945 \\
\hline $\mathrm{t} \times \ln Y 1$ & 0.0175 & 1.0586 & -0.0106 & -0.9197 \\
\hline $\mathrm{t} \times \ln \mathrm{Y} 2$ & $-0.0275^{*}$ & -1.8599 & 0.0091 & 0.9478 \\
\hline $\mathrm{t} \times \ln \mathrm{Y} 3$ & 0.0034 & 0.3316 & -0.0014 & -0.1788 \\
\hline $\mathrm{t} \times \ln (\mathrm{P} 1 / \mathrm{P} 2)$ & -0.0039 & -0.4800 & 0.0074 & 0.6864 \\
\hline $\mathrm{t} \times \ln (\mathrm{P} 3 / \mathrm{P} 2)$ & -0.0007 & -0.0753 & 0.0083 & 1.4061 \\
\hline $\mathrm{T}$ & 0.0082 & 0.0577 & 0.1327 & 1.4760 \\
\hline$t^{2}$ & 0.0203 & 1.5936 & $-0.0197^{* *}$ & -2.1555 \\
\hline$\sigma_{\mu}^{2}$ & $0.0226^{* * *}$ & 5.5345 & $0.0139 * * *$ & 11.9827 \\
\hline$\gamma$ & $0.9144^{* * *}$ & 4.9264 & $0.1272^{* *}$ & 2.0110 \\
\hline Log likelihood function & 180.3048 & & 191.6664 & \\
\hline LR test & 64.5084 & & 87.2316 & \\
\hline
\end{tabular}

Note: ${ }^{* * *}$ denotes $1 \%$ significance level; ${ }^{* *}$ denotes $5 \%$ significance level; ${ }^{*}$ denotes $10 \%$ significance level.

The study used the inefficiency model of the banks in the developed and developing economies in Asia to identify the impact of the ESG and financial variables on the cost inefficiency of the banks. Table 6 presents the empirical results for the two groups of Asian banks based on the cost inefficiency model. 
Table 6. Results of Cost Inefficiency Model.

\begin{tabular}{ccccc}
\hline \multirow{2}{*}{ Variables } & \multicolumn{2}{c}{ Developed Economy } & \multicolumn{2}{c}{ Developing Economy } \\
\cline { 2 - 5 } & Coefficients & t Values & Coefficients & t Values \\
\hline Constant & 0.6364 & 1.3258 & $0.8446^{* * *}$ & 7.7130 \\
E & $-0.4687^{* *}$ & -2.3741 & -0.0160 & -0.2328 \\
S & $0.4608^{* * *}$ & 2.7570 & $-0.1685^{* * *}$ & -3.5102 \\
G & $0.4132^{* * *}$ & 3.0017 & $-0.1043^{* * *}$ & -2.3322 \\
NPL ratio & $0.0511^{* *}$ & 2.4063 & $0.0042^{* * *}$ & 2.7383 \\
BIS ratio & $-0.0304^{* * *}$ & -3.4008 & $-0.0085^{* * *}$ & -5.0861 \\
Cost to income ratio & $-0.0202^{* * *}$ & -5.6154 & $0.0020^{* * *}$ & 2.9572 \\
Loan loss reserve ratio & $0.0003^{*}$ & 1.8508 & -0.0001 & -1.1099 \\
Liquidity ratio & -0.0011 & -0.6728 & -0.0008 & -1.2930 \\
Non-interest expense ratio & -0.0211 & -1.2653 & -0.0004 & -0.1476 \\
\hline Note: ${ }^{* * *}$ denotes 1\% significance level; ${ }^{* *}$ denotes $5 \%$ significance level; ${ }^{*}$ denotes $10 \%$ significance level.
\end{tabular}

\subsection{ESG}

\subsubsection{Environmental (E)}

The results in Table 6 show that in the developed Asian economies, the environmental variables are negatively related to bank cost inefficiency at the $5 \%$ significance level. However, in the developing Asian economies, the environmental variables are negatively correlated with bank cost inefficiency but insignificantly.

The outcome suggests that in developed Asian economies, environmentally friendly activities such as reducing water pollution, eliminating carbon dioxide emissions, and using renewable energy, not increased the intangible values of the banks, but also tangible values. The environmental activities disclosed in the banks' annual reports enhanced bank reputation and simultaneously diminished bank cost inefficiency. These results are consistent with previous studies that found that bank investments in environmentally friendly practices were able to save energy and fuel costs for banks considerably due to the bank-wide inclusion of the relatively larger scale of the energy-saving plans $[12,18,23,26]$. However, in the developing Asian economies, banks are unable to recover the costs incurred for implementing environmentally friendly activities. These findings correspond to the literature in that although banks spend money reducing environmental harm, these banks suffer from poor environmental regulations and government incentives. Therefore, banks in the developing economies increased expenditure on the necessary equipment and facilities to improve their environments but failed to reduce costs in the long run.

Therefore, $\mathrm{H} 1$ is accepted for developed Asian economies but rejected for developing Asian economies.

\subsubsection{Social (S)}

The results in Table 6 indicate that in the developed Asian economies, social variables have a positive relationship with bank cost inefficiency at the $1 \%$ significance level. In the developed Asian economies, banks that implement social welfare programs for stakeholders such as fair employee salaries, safe work environment, and community services increased costs that cannot be compensated for by higher revenue. This outcome is consistent with the literature in that the large banks in the developed economies are expected to show altruistic behavior by caring for employees and serving the communities, hence these social activities did not create more business for these banks $[9,11,23,26]$.

However, in the developing Asian economies, social variables have a negative relationship with bank cost inefficiency at the $1 \%$ significance level. This result suggests that socially responsible activities are considered strategic behavior for the banks in developing economies. Such a finding is consistent with the literature that care for employees and neighbors enhances bank reputation and consumer confidence, thus attracting more customers to interact with socially responsible banks. Consumers could even be willing to pay a higher price to purchase financial products and services from banks that frequently 
announced new social programs. Furthermore, the higher revenue generated by these banks enables them to hire more qualified workers to enhance their cost efficiency [43].

Therefore, $\mathrm{H} 2$ is rejected for developed Asian economies but accepted for developing Asian economies.

\subsubsection{Governance (E)}

The results in Table 6 reveal that in the developed economies, the governance variables have a positive relationship with bank cost inefficiency at the $1 \%$ significant level. In the developed economies, the design of innovative products and services, gender equality, and peace-building activities resulted in higher costs than profits. Such a phenomenon is consistent with prior studies [12,23,31] and occurs because the implementation of corporate governance is internal. The additional costs for such internal improvements cannot be directly turned into more business and higher revenue for banks. This outcome suggests that because the banks in the developed economies tend to be more globalized, they are anticipated to align with the UN guidelines and managed according to international standards. These banks are expected to invest in corporate governance to maintain their reputation and service quality. However, these efforts simply meet the customers' expectations and do not attract more customers. These efforts can be regarded as altruistic behavior [5].

In contrast, in the developing economies, the governance variables have a negative relationship with bank cost inefficiency at the $1 \%$ significance level. This outcome implies that these banks can attract more customers or increase customer willingness to purchase more financial products or services as a result of bank investments in governance activities. Such acts are considered strategic behavior for banks because their improvement in bank management is likely to change customer perception and differentiate themselves from the banks that do not pay attention to governance. Hence, banks in developing economies can attract customers and generate higher revenue due to improved governance which can be announced publicly.

Therefore, H3 is rejected for developed Asian economies but accepted for developing Asian economies.

\subsection{Bank Financial Ratios}

Regarding bank financial indicators, three variables are worth noting. First, NPL has a significantly positive relationship with bank cost inefficiency in both developed and developing economies. Second, BIS adequacy ratio has a significantly negative relationship with bank cost inefficiency in both developed and developing economies. This outcome suggests that banks should focus on reducing NPL and increasing bank capital to improve cost efficiency.

Third, the cost-to-income ratio has a significantly negative relationship with bank cost inefficiency in the developed economies but a significantly positive relationship with bank cost inefficiency in the developing economies. Such results mean that increasing costs in the developed economies increases bank cost inefficiency. However, increasing costs in the developing economies decreased bank cost inefficiency. The outcome implies that the banks in the developing economies can generate greater returns for their spending [46].

\subsection{SMF Cost Function}

In the second step of the analysis, we adopted SMF to estimate the metafrontier cost functions for the two groups of banks. Before estimating the metafrontier cost function, we conducted the LR test to determine whether a difference exists between the two groups of banks in terms of the stochastic frontier. The null hypothesis was set as $H_{0}: \beta_{F}=\beta_{N}$, which means that no difference existed between the two bank groups. The opposite $\mathrm{H}_{1}$ means a significant difference existed between the two bank groups. The LR test statistic was 218.56, which was higher than the threshold calculated by Chi-square $\chi_{0.01,27}^{2}=46.96$, thus rejecting $\mathrm{H}_{0}$ at a $1 \%$ significance level. The results of the T-test and the LR test both 
confirm a difference in the stochastic frontier between the two groups of banks. Therefore, it is feasible to estimate the metafrontier cost function.

To conduct SMF, we added a bank-specific variable, namely, asset size, and macroeconomic variables (unemployment rate, GDP per capita) to investigate their impact on bank cost efficiency. Table 7 contains the metafrontier cost function results estimated using SMF.

Table 7. SMF cost function results.

\begin{tabular}{|c|c|c|}
\hline \multirow{2}{*}{ Variables } & \multicolumn{2}{|c|}{ SMF } \\
\hline & Estimated Coefficients & t Values \\
\hline Constant & $7.3720^{* * *}$ & 15.4556 \\
\hline $\ln Y 1$ & 0.0053 & 0.0840 \\
\hline $\ln Y 2$ & $0.8821^{* * *}$ & 9.5263 \\
\hline $\ln Y 3$ & $2.7400^{* * *}$ & 5.3133 \\
\hline $\ln (\mathrm{P} 1 / \mathrm{P} 2)$ & $0.5957^{* * *}$ & 8.5457 \\
\hline $\ln (\mathrm{P} 3 / \mathrm{P} 2)$ & 0.0025 & 0.0146 \\
\hline $1 / 2 \times(\ln Y 1)^{2}$ & $0.9254^{* * *}$ & 12.6705 \\
\hline $1 / 2 \times(\ln Y 2)^{2}$ & $0.6576^{* * *}$ & 4.6619 \\
\hline $1 / 2 \times(\ln Y 3)^{2}$ & $2.9270^{* * *}$ & 29.6286 \\
\hline $\ln Y 1 \times \ln Y 2$ & $0.8331^{* * *}$ & 8.5519 \\
\hline $\ln Y 1 \times \ln Y 3$ & $2.7987 * * *$ & 22.6504 \\
\hline $\ln Y 2 \times \ln Y 3$ & $2.6337^{* * *}$ & 19.6825 \\
\hline $1 / 2 \times[\ln (\mathrm{P} 1 / \mathrm{P} 2)]^{2}$ & $0.9316^{* * *}$ & 18.0750 \\
\hline $1 / 2 \times[\ln (\mathrm{P} 3 / \mathrm{P} 2)]^{2}$ & 0.1687 & 0.2911 \\
\hline $\ln (\mathrm{P} 1 / \mathrm{P} 2) \times \ln (\mathrm{P} 3 / \mathrm{P} 2)$ & $0.7532 * * *$ & 4.8917 \\
\hline $\ln Y 1 \times \ln (\mathrm{P} 1 / \mathrm{P} 2)$ & 0.1425 & 0.9214 \\
\hline $\ln \mathrm{Y} 1 \times \ln (\mathrm{P} 3 / \mathrm{P} 2)$ & 0.0952 & 0.3478 \\
\hline $\ln Y 2 \times \ln (\mathrm{P} 1 / \mathrm{P} 2)$ & $2.4138^{* * *}$ & 6.1978 \\
\hline $\ln \mathrm{Y} 2 \times \ln (\mathrm{P} 3 / \mathrm{P} 2)$ & $0.6266^{* * *}$ & 3.5068 \\
\hline $\ln \mathrm{Y} 3 \times \ln (\mathrm{P} 1 / \mathrm{P} 2)$ & $1.5016^{* * *}$ & 6.2416 \\
\hline $\ln \mathrm{Y} 3 \times \ln (\mathrm{P} 3 / \mathrm{P} 2)$ & $1.6195 *$ & 1.9170 \\
\hline $\mathrm{t} \times \ln \mathrm{Y} 1$ & -0.0503 & -0.0726 \\
\hline $\mathrm{t} \times \ln \mathrm{Y} 2$ & 0.1993 & 0.4495 \\
\hline $\mathrm{t} \times \ln \mathrm{Y} 3$ & 1.3797 & 1.4036 \\
\hline $\mathrm{t} \times \ln (\mathrm{P} 1 / \mathrm{P} 2)$ & 0.3690 & 0.3721 \\
\hline $\mathrm{t} \times \ln (\mathrm{P} 3 / \mathrm{P} 2)$ & 1.3561 & 1.4119 \\
\hline $\mathrm{T}$ & 0.0814 & 0.1906 \\
\hline$t^{2}$ & 0.6157 & 1.1474 \\
\hline Constant term & $0.8028^{* * *}$ & 7.1214 \\
\hline Asset size & $-0.04478^{* * *}$ & -5.7462 \\
\hline Unemployment rate & $0.02088^{* * *}$ & 4.4767 \\
\hline GDP per capita & $-0.03738^{* * *}$ & -2.8298 \\
\hline$\sigma_{\mu}^{2}$ & $0.02218^{* * *}$ & 16.5001 \\
\hline$\gamma$ & $0.07308 * * *$ & 3.0538 \\
\hline Log likelihood function & & \\
\hline LR test & & \\
\hline
\end{tabular}

Note: ${ }^{* * *}$ denotes $1 \%$ significance level; ${ }^{* *}$ denotes $5 \%$ significance level; ${ }^{*}$ denotes $10 \%$ significance level.

The results in Table 7 show that asset size has a negative relationship with cost inefficiency. This outcome means that larger banks can reduce cost inefficiency due to their economy of scale. The unemployment rate has a positive relationship with cost inefficiency. The GDP per capita has a negative relationship with bank cost inefficiency. The results using macroeconomic factors indicate that higher unemployment increases bank costs. In contrast, higher GDP per capita increases bank cost efficiency.

\subsection{TGR and MCE}

The SMF regression method was used to compute both the TGR and MCE of the banks in the developed and developing Asian economies. Figure 1 shows the TGR of the 
two groups of banks. The banks in the developed economies had average TGR values between 1.0065 and 1.0070. The banks in the developing economies had average TGR values between 1.0739 and 1.1134. The TGR values of the banks in the developed economies are closer to one (1) than those of the banks in the developing economies. The bank group cost of the developed Asian economies is closer to the metafrontier cost, which means they managed costs better. The TGR of banks in the developing economies rose from 2015 to 2018. The increase in the technology gaps each year from 2015 to 2018 suggests that banks in the developing Asian economies deteriorate in their abilities to control costs.

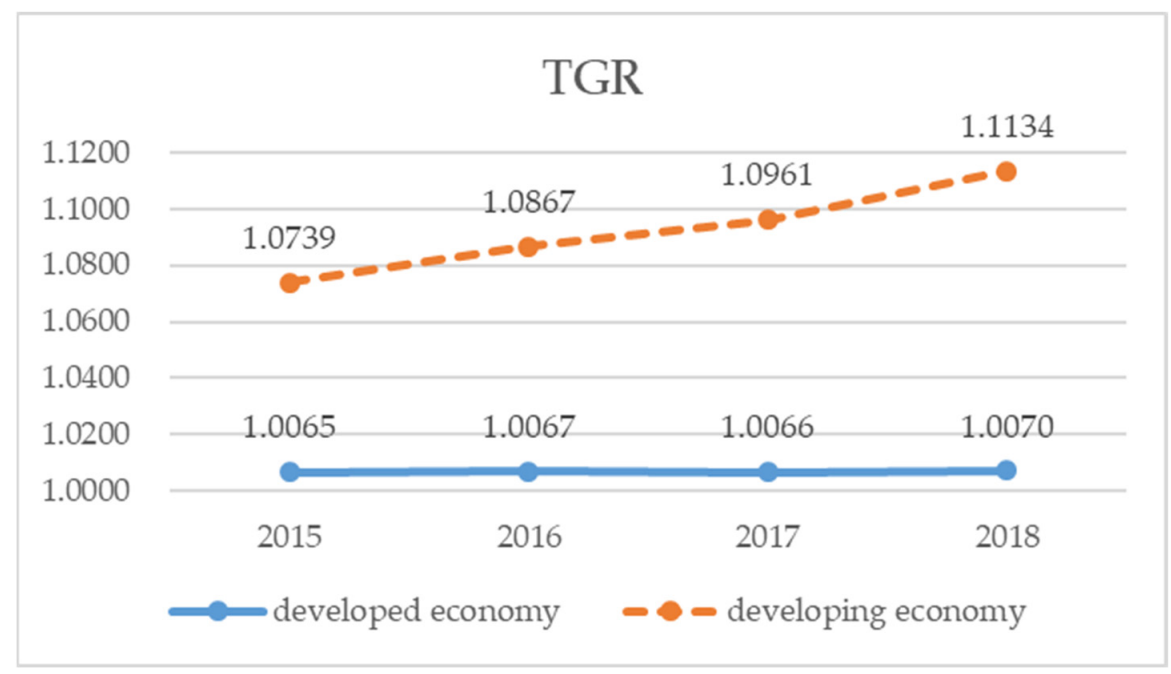

Figure 1. TGR of the banks in the developed and developing economies.

Figure 2 depicts the MCE of the two groups of banks in Asia. The banks in the developed economies had average MCE values between 1.3206 and 1.4242. The banks in the developing economies had average MCE values between 1.6638 and 1.6477. The results indicate that the MCE of the banks in the developed economies is superior to that of the banks in the developing economies because the values are closer to one (1). Overall, banks in the developed economies were more cost-efficient considering the ESG, bank-specific and macroeconomic variables altogether. However, the cost inefficiency of these banks continued to rise each year, notably from 2015 to 2016 and slightly from 2016 to 2018. This outcome suggests that the disclosure of ESG activities caused banks in the developed economies to be cost inefficient. It can be inferred that the ESG activities were considered altruistic behavior for these banks with costs not turned into more profits.

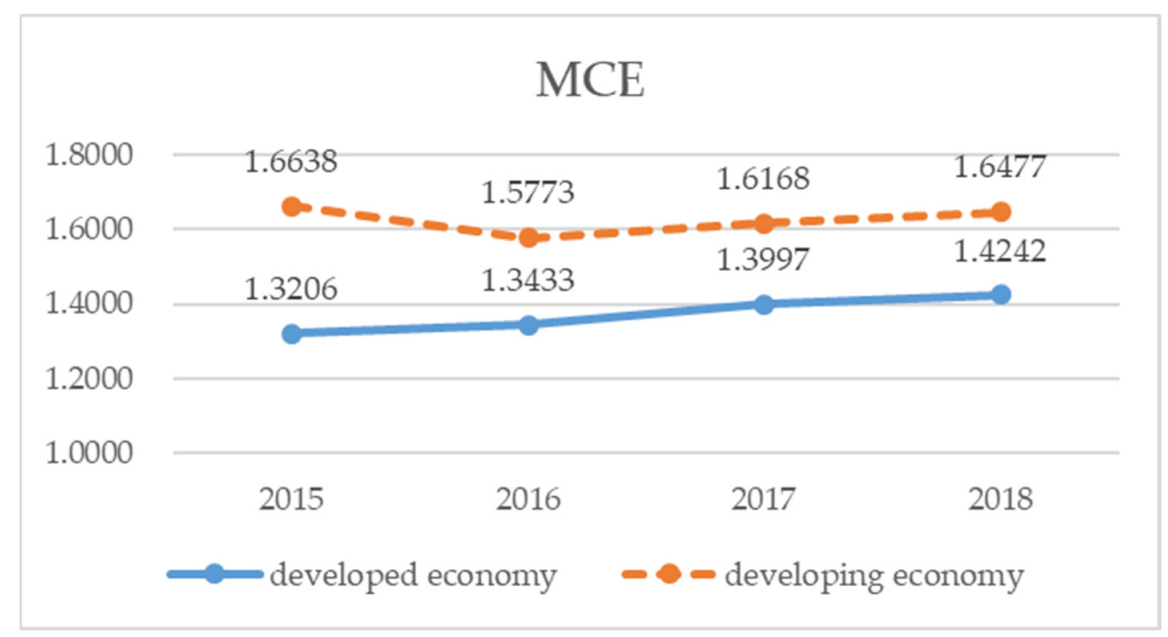

Figure 2. MCE of the banks in developed and developing economies. 


\section{Robustness Test}

We conducted the robustness tests to confirm the impact of ESG on bank cost efficiency. The results show that the banks in the developed economies have significantly higher cost efficiency than the ones in the developing economies concerning CE, TRG, and MCE. Therefore, the results from the division of bank groups are robust.

\section{Conclusions}

The concept of ESG has gained increasing importance around the world in the last decade. Significantly, the UN specified 17 SDGs indicating actions in each of the ESG areas. An increasing number of companies are using ESGs as a measure of performance in addition to the widely used financial (bank-specific and macroeconomic) ratios. In the last ten years, Asian banks have grown rapidly and are expected to surpass the banks in other continents in terms of personal financial assets by 2025. Therefore, the sustainability of the Asian banks must be maintained to stabilize the economy. However, it remains unclear whether the additional costs incurred by banks due to ESG practices can be compensated for by higher revenue. This study applied a two-step analysis comprising SFA and SMF to examine the impact of ESG (17 SDGs) and financial indicators (bank-specific and macroeconomic) on the cost efficiency of the banks in developed and developing economies in Asia from 2015 to 2018.

In the first step of the analysis, we applied SFA. The results indicate that environmental variables increased the cost efficiency of the banks only in the developed Asian economies. Therefore H1 (Environmental variables have a positive impact on bank cost efficiency) is partially accepted. The social variables decreased the cost efficiency of the banks in the developed Asian economies but increased the cost efficiency of the banks in the developing Asian economies. Therefore, H1 (social variables have a positive impact on bank cost efficiency) is partially accepted. Governance decreased the cost efficiency of the banks in the developed Asian economies but increased the cost efficiency of the banks in the developing Asian economies. Therefore, H3 (Governance has a positive impact on bank cost efficiency) is partially accepted. Overall, only environmentally friendly activities helped banks in the developed economies to become cost efficient, possibly due to the large-scale energy saving schemes implemented bank-wide. Socially responsible activities and good governance aided banks in the developing economies to become more cost efficient, probably due to enhanced reputation and consumer confidence.

In addition, this study examined the impact of bank-specific factors on bank cost efficiency. The results from the cost-to-income ratio varied. Increasing costs in the developed economies increased bank cost inefficiency. However, increasing costs in the developing economies decreased bank cost inefficiency. This outcome suggests that banks in the developing economies were able to generate more revenues with more spending.

In the second step of the analysis, the SMF approach was utilized to compare the TGR and MCE for the two groups of banks. The results indicate that the banks in the developed economies had higher cost efficiency and a smaller technology gap than their counterparts in the developing economies. More importantly, banks in the developing Asian economies increased the technology gap each year, indicating that they deteriorated in their abilities to control costs effectively. The MCE of the banks in the developed economies is superior to that of the banks in the developing economies. Despite their higher cost efficiency, the banks in the developed economies continued to rise from 2015 to 2018, which implies that the overall ESG costs did not allow the banks in the developed economies to generate more revenues.

The current findings confirm that implementing environmentally-friendly practices such as using clean water, green energy, and recyclable products increased bank cost efficiency in the developed Asian economies. Therefore, these banks are recommended to focus on environmental activities. The empirical evidence also indicates that executing socially responsible activities, such as care for employees and community, and governance increased the bank cost efficiency in the developing Asian economies. Therefore, banks 
in the developing Asian economies could engage more in socially responsible programs and governance. In addition, the results of this study may help investors in selecting banks with different ESG emphases.

Asian banks have gained increasing importance in the last decade with more than $30 \%$ of the top 100 banks in the world originating in Asia. Although the results of this study pertain to Asia, they could be generalized to banks in other developed and developing economies. The findings of the ways ESG impacts cost efficiency not only benefit investors and bank managers, but also the entire banking sector and the global economy seeking sustainable developments. In particular, the developing banks that emphasize ESG practices are likely to become more financially sustainable due to higher cost efficiency and a stronger connection with society. Moreover, banks that allocate more resources to ESG activities can better fulfill the needs of individuals and organizations, thus propelling global economic growth and sustainability.

Future research may aim at analyzing the direct impact of SDGs on value creation for banks, such as the actions which could be adopted to improve shareholder interests or customer satisfaction. The differences in the SDG approaches practiced by banks may be scrutinized to identify those which are most effective. In this way, we could deepen our understanding of the ways in which ESG impacts the financial industry to achieve sustainable development.

Author Contributions: Conceptualization, H.-Y.C.; methodology, L.-W.L.; software, Y.-L.L.; validation, H.-Y.C.; formal analysis, H.-Y.C. and L.-W.L.; investigation, L.-W.L.; resources, Y.-L.L.; data curation, Y.-L.L.; writing-original draft preparation, L.-W.L. and Y.-L.L.; writing-review and editing, H.-Y.C.; visualization, L.-W.L.; supervision, H.-Y.C.; project administration, L.-W.L. All authors have read and agreed to the published version of the manuscript.

Funding: This research received no external funding.

Institutional Review Board Statement: Not applicable.

Informed Consent Statement: Not applicable.

Acknowledgments: The authors would like to thank the anonymous referees for providing helpful comments and suggestions which lead to the improvement of the paper.

Conflicts of Interest: The authors declare no conflict of interest.

\section{References}

1. Ghosh, A. What drives banking industry competition in developing countries? J. Econ. Dev. 2018, 43, 1-20. [CrossRef]

2. Gemar, P.; Gemar, G.; Guzman-Parra, V. Modeling the sustainability of bank profitability using partial least squares. Sustainability 2019, 11, 4950. [CrossRef]

3. Karray, S.C.; Chichti, J.E. Bank size and efficiency in developing countries: Intermediation approach versus value-added approach and impact of non-traditional activities. Asian Econ. Financ. Rev. 2013, 3, 593.

4. Battese, G.E.; Coelli, T.J. A model for technical inefficiency effects in a stochastic frontier production function for panel data. Empir. Econ. 1995, 20, 325-332. [CrossRef]

5. Forgione, A.F.; Laguir, I.; Staglianò, R. Effect of corporate social responsibility scores on bank efficiency: The moderating role of institutional context. Corp. Soc. Responsib. Environ. Manag. 2020, 27, 2094-2106. [CrossRef]

6. Huang, C.J.; Huang, T.-H.; Liu, N.-H. A new approach to estimating the metafrontier production function based on a stochastic frontier framework. J. Prod. Anal. 2014, 42, 241-254. [CrossRef]

7. Kamarudin, F.; Sufian, F.; Nassir, A.M.; Anwar, N.A.M.; Hussain, H.I. Bank efficiency in Malaysia a DEA approach. J. Central Bank. Theory Pract. 2019, 8, 133-162. [CrossRef]

8. Burgstaller, J. Retail-bank efficiency: Nonstandard goals and environmental determinants. Ann. Public Coop. Econ. 2020, 91, 269-301. [CrossRef]

9. Miralles-Quirós, M.M.; Miralles-Quirós, J.L.; Hernandez, J.R. The impact of environmental, social, and governance performance on stock prices: Evidence from the banking industry. Corp. Soc. Responsib. Environ. Manag. 2019, 26, 1446-1456. [CrossRef]

10. Bătae, O.M.; Dragomir, V.D.; Feleagă, L. Environmental, social, governance (ESG), and financial performance of European banks. J. Account. Manag. Inf. Syst. 2020, 19, 480-501. [CrossRef]

11. Miralles-Quirós, M.M.; Miralles-Quirós, J.L.; Hernandez, J.R. ESG performance and shareholder value creation in the banking industry: International differences. Sustainability 2019, 11, 1404. [CrossRef] 
12. Azmi, W.; Hassan, M.K.; Houston, R.; Karim, M.S. ESG activities and banking performance: International evidence from emerging economies. J. Int. Financ. Mark. Inst. Money 2021, 70, 101277. [CrossRef]

13. Torre, M.; Mango, F.; Cafaro, A.; Leo, S. Does the ESG index affect stock return? Evidence from the eurostoxx 50. Sustainability 2020, 12, 6387. [CrossRef]

14. United Nations. Principles for Responsible Investment. 2020. Available online: https://www.unpri.org/sustainability-issues (accessed on 7 July 2021).

15. United Nations. THE 17 GOALS—Sustainable Development. Available online: https://sdgs.un.org/goals (accessed on 7 July 2021).

16. Dahl, J.; Sengupta, J.; Ng, E. Future of Asia Banking—How Asia Is Reinventing Banking for the Digital Age; McKinsey \& Company: New York, NY, USA, 2020. Available online: https:/ / www.mckinsey.com/featured-insights/asia-pacific/how-asia-is-reinventingbanking-for-the-digital-age (accessed on 7 July 2021).

17. S\&P Global Market INTELLIGENCE. The world's 100 largest banks. 2021. Available online: https://www.spglobal.com/ marketintelligence/en/news-insights/research/the-worlds-100-largest-banks-2021 (accessed on 7 July 2021).

18. Crespi, F.; Migliavacca, M. The determinants of ESG rating in the financial industry: The same old story or a different tale? Sustainability 2020, 12, 6398. [CrossRef]

19. Harvard Law School Forum on Corporate Governance. UN Sustainable Development Goals—The Leading ESG Framework for Large Companies. 2018. Available online: https:/ / corpgov.law.harvard.edu/2018/10/04/un-sustainable-development-goalsthe-leading-esg-framework-for-large-companies/ (accessed on 7 July 2021).

20. Freeman, R.E.; Harrison, J.S.; Wicks, A.C.; Parmar, B.L.; De Colle, S. Stakeholder Theory. The State of the Art; Cambridge University Press: New York, NY, USA, 2010.

21. Eccles, R.G.; Ioannou, I.; Serafeim, G. The Impact of Corporate Sustainability on Organizational Processes and Performance. Manag. Sci. 2014, 60, 2835-2857. [CrossRef]

22. Shakil, M.H.; Mahmood, N.; Tasnia, M.; Munim, Z.H. Do environmental, social and governance performance affect the financial performance of banks? A cross-country study of emerging market banks. Manag. Environ. Qual. Int. J. 2019, 30, 1331-1344. [CrossRef]

23. Buallay, A. Is sustainability reporting (ESG) associated with performance? Evidence from the European banking sector. Manag. Environ. Qual. Int. J. 2019, 30, 98-115. [CrossRef]

24. Miras-Rodríguez, M.D.M.; Carrasco-Gallego, A.; Escobar-Pérez, B. Has the CSR engagement of electrical companies had an effect on their performance? A closer look at the environment: Has CSR an effect on the performance? Bus. Strat. Environ. 2015, 24, 819-835. [CrossRef]

25. Dell'Atti, S.; Trotta, A.; Iannuzzi, A.P.; DeMaria, F. Corporate social responsibility engagement as a determinant of bank reputation: An empirical analysis. Corp. Soc. Responsib. Environ. Manag. 2017, 24, 589-605. Available online: https://onlinelibrary.wiley.com/ doi/full/10.1002/csr.1430 (accessed on 1 October 2021).

26. Di Tommaso, C.; Thornton, J. Do ESG scores effect bank risk taking and value? Evidence from European banks. Corp. Soc. Responsib. Environ. Manag. 2020, 27, 2286-2298. [CrossRef]

27. Freeman, R.E. Strategic Management: A Stakeholder Approach; Pitman Publishing: Boston, MA, USA, 1984.

28. Kaymak, T.; Bektas, E. Corporate social responsibility and governance: Information disclosure in multinational corporations. Corp. Soc. Responsib. Environ. Manag. 2017, 24, 555-569. [CrossRef]

29. Jensen, M.C.; Meckling, W.H. Theory of the firm: Managerial behavior, agency costs and ownership structure. J. Financ. Econ. 1976, 3, 305-360. [CrossRef]

30. Barnea, A.; Rubin, A. Corporate social responsibility as a conflict between shareholders. J. Bus. Ethics 2010, 97, 71-86. [CrossRef]

31. El Khoury, R.; Nasrallah, N.; Alareeni, B. ESG and financial performance of banks in the MENAT region: Concavity-convexity patterns. J. Sustain. Financ. Investig. 2021, 1-25. [CrossRef]

32. Birindelli, G.; Dell'Atti, S.; Iannuzzi, A.P.; Savioli, M. Composition and activity of the board of directors: Impact on ESG performance in the banking system. Sustainability 2018, 10, 4699. [CrossRef]

33. Walheer, B. Aggregation of metafrontier technology gap ratios: The case of European sectors in 1995-2015. Eur. J. Oper. Res. 2018, 269, 1013-1026. [CrossRef]

34. Liang, L.-W.; Chang, H.-Y.; Liu, J.-H. Does corporate social responsibility make banks more cost efficient? Taiwan J. Appl. Econ. 2019, 106, 109-148. [CrossRef]

35. International Monetary Fund. World Economic Outlook. 2017. Available online: https://www.imf.org/en/Publications/WEO/ Issues/2017/09/19/world-economic-outlook-october-2017 (accessed on 1 July 2021).

36. Sealey, C.W.; Lindley, J.T. Inputs, outputs, and a theory of production and cost at depository financial institutions. J. Financ. 1977, 32, 1251-1266. [CrossRef]

37. Nourani, M.; Devadason, E.; Chandran, V. Measuring technical efficiency of insurance companies using dynamic network dea: An intermediation approach. Technol. Econ. Dev. Econ. 2018, 24, 1909-1940. [CrossRef]

38. Altunbas, Y.; Liu, M.-H.; Molyneux, P.; Seth, R. Efficiency and risk in Japanese banking. J. Bank. Financ. 2000, $24,1605-1628$. [CrossRef]

39. Altunbas, Y.; Evans, L.; Molyneux, P. Bank ownership and efficiency. J. Money Crédit. Bank. 2001, 33, 926-954. [CrossRef] 
40. Gaganis, C.; Pasiouras, F. Financial supervision regimes and bank efficiency: International evidence. J. Bank. Financ. 2013, 37, 5463-5475. [CrossRef]

41. Weill, L. Measuring cost efficiency in European banking: A Comparison of frontier techniques. J. Prod. Anal. 2004, 21, 133-152. [CrossRef]

42. Fries, S.; Taci, A. Cost efficiency of banks in transition: Evidence from 289 banks in 15 post-communist countries. J. Bank. Financ. 2005, 29, 55-81. [CrossRef]

43. Huang, T.H.; Shen, C.H.; Wu, M.W.; Chang, Y.C. Does CSR engagement affect banking efficiency in the context of a stochastic cost frontier? J. Financ. Stud. 2019, 27, 1-32. [CrossRef]

44. Pasiouras, F.; Kosmidou, K. Factors influencing the profitability of domestic and foreign commercial banks in the European Union. Res. Int. Bus. Financ. 2007, 21, 222-237. [CrossRef]

45. Liang, L.-W.; Cheng, C.-P.; Lin, Y. Determinants of banking efficiency and survival in Taiwan with consideration of the real management cost. Emerg. Mark. Financ. Trade 2020, 56, 1003-1023. [CrossRef]

46. Liang, L.-W.; Chang, H.-Y.; Shao, H.-L. Does sustainability make banks more cost efficient? Glob. Financ. J. 2018, 38, 13-23. [CrossRef]

47. Christensen, L.R.; Jorgenson, D.W.; Lau, L.J. Transcendental logarithmic production frontiers. Rev. Econ. Stat. 1973, 55, 28-45. [CrossRef]

48. Huang, T.-H.; Wang, M.-H. Estimation of scale and scope economies in multiproduct banking: Evidence from the Fourier flexible functional form with panel data. Appl. Econ. 2004, 36, 1245-1253. [CrossRef]

49. Humphrey, D.B.; Vale, B. Scale economies, bank mergers, and electronic payments: A spline function approach. J. Bank. Financ. 2004, 28, 1671-1696. [CrossRef]

50. Kraft, E.; Hofler, R.; Payne, J. Privatization, foreign bank entry and bank efficiency in Croatia: A Fourier-flexible function stochastic cost frontier analysis. Appl. Econ. 2006, 38, 2075-2088. [CrossRef]

51. Allen, L.; Rai, A. Operational efficiency in banking: An international comparison. J. Bank. Financ. 1996, 20, 655-672. [CrossRef]

52. Berger, A.N.; Mester, L.J. Inside the black box: What explains differences in the efficiencies of financial institutions? J. Bank. Financ. 1997, 21, 895-947. [CrossRef]

53. Avdjiev, S.; Giudici, P.; Spelta, A. Measuring contagion risk in international banking. J. Financ. Stab. 2019, 42, 36-51. [CrossRef]

54. Abedifar, P.; Giudici, P.; Hashem, S.Q. Heterogeneous market structure and systemic risk: Evidence from dual banking systems. J. Financ. Stab. 2017, 33, 96-119. [CrossRef] 